\title{
A CRITICAL REVIEW \\ SOME ASPECTS OF THE STRUCTURE OF THE HYPOTHALAMUS
}

\author{
BY
}

\section{G. M. GRIFFITHS}

THAT small region of the brain described as the hypothalamus has sprung into prominence of recent years. In atlases of the brain based on myelin staining methods, the area is scarcely mentioned, still less considered in detail. Of recent years, however, many papers have appeared giving cytological details of the structure in man and in various animals, resulting in a wealth of information and a great deal of confusion in terminology. Comparative anatomical studies reveal that certain cell groups are found constantly throughout the phylæ, but other groups are less well differentiated, or not represented in some species. Here again we find difficulties in correlating the findings of various workers, some using broad and definite groups, and others subdividing these and giving names to the less well-determined cell groups.

The nerve fibres associated with this region are nearly all unmyelinated, and this gives rise to difficulties in the precise localization of tracts. The silver impregnation methods which must be used are notoriously selective, and in the main show a jumble of fine fibrils, the exact course of which is extremely difficult to trace. Degeneration methods are particularly difficult. Another peculiar difficulty in the study of this region lies in the normal appearance of cells of many of the groups. They have an appearance usually associated with degenerative processes and this misled many workers till the fact was recognized.

The relationship between the pituitary body and the hypothalamus presents an aspect of great importance and interest, and from the anatomical point of view, of great conflict of opinion.

In view of the functional importance of the region and the mass of experimental work that has been performed, it seems suitable to review the present state of knowledge of the structure, especially of the species variations and the debatable aspects.

Nuclei.-In man the hypothalamus is bounded by the optic chiasma and tracts anteriorly and laterally, and extends to the mamillary bodies, which are sometimes included in the area, but should more properly be considered with the subthalamic area. The floor of the third ventricle is included.

Greving, in a series of papers from 1923 to 1926 described the region on 
the basis of series of sections stained by silver impregnations. Gagel in 1928 made a study of Nissl series of the human hypothalamus. These authors used certain names of cell groups, which are in common usage, but do not command universal acceptance. Other names had been given to homologous structures by workers who had studied the structures in animals. Koikegami (1938) has attempted to correlate the names. There are, however, two obvious cell groups which are recognized in all animal forms-the paraventricular and the supraoptic nuclei.

The paraventricular nucleus of Greving and Gagel, called nucleus filiformis by several comparative anatomists, consists of a mass of closely packed cells lying roughly parallel with the wall of the third ventricle, between it and the fornix. In the periphery of the nucleus the cells are more scattered. The cells are fairly large with a large nucleus having a well-marked nucleolus. The nucleus usually lies eccentrically, with a clear space surrounding it, and the tigroid substance is collected round the periphery of the cell. In many of the cells vacuoles may be seen, varying in size and numbers. The cells may be multipolar or bipolar or even unipolar. As there is a wide capillary ramification between the cells, even forming loops around some, this nucleus is very vascular indeed. Gaupp and Scharrer (1935) have described the presence of capillaries within the cells of the nucleus.

The supraoptic nucleus of Gagel and Greving-nucleus tangentialis of others -is a closely packed mass of cells applied to the optic nerve, extending anteriorly from just behind the chiasma to about two-thirds of its length. There are two main parts : the dorso-lateral and the ventro-medial parts, linked by a chain of cells circling the nerve. The dorso-lateral part is the larger and is more densely packed with cells ; it is well defined and on its external aspect reaches near the pial surface of the brain. The cells resemble those of the paraventricular nucleus. Laruelle (1934) points out that the cells have the appearance of a shoal of fish when cut parallel to the optic nerve. In this plane the cells appear bipolar. The vascularity of the nucleus is as great as that of the paraventricular nucleus. The subdivisions of this nucleus have been stressed by some writers, but Recordon and Griffiths (1938) in an anophthalmic baby, where no optic nerve was present, found the supraoptic nucleus as a flat plate of cells; these authors believe that the divisions are therefore the result of the presence of the optic nerve.

Lying between these two main masses of cells are some small scattered groups of cells having similar characters. These groups have been called separately nucleus supraopticus accessorius by Nicolesco and Nicolesco (1929), or nucleus paraventricularis accessorius by Greving (1925). It is pointed out by Hechst (1930) that in animals these cells are closely applied to a vessel. If the vessels are cut transversely in sections the cell groups appear as six or eight cells close to the vessels, but if the vessels are cut obliquely the groups appear larger. Nicolesco and Nicolesco considered these groups to have a richer vascular supply than the main nuclear groups. With a vessel cut longitudinally the cells appear to be closely applied to it along its length and the groups of cells may then appear to be branches from the main supraoptic nucleus. These 
"accessory" nuclei are probably structurally and functionally one with the supraoptic nucleus, and may form a type of link with the paraventricular nucleus.

The nucleus tuberis in man is described as containing two or three nuclear groups. These lie near the pial surface between the supraoptic nucleus and the infundibulum. In infants it appears that there are two nuclei, one reniform and one more spherical. When three nuclei are described as seen in a section, it is possible that the cut ends of the reniform nucleus make up two of them. The nuclei are easily discernible in brains of the young, but usually less obvious in those of older subjects. Sometimes they form projections on the external surface of the brain, to which the name tuberal tubercles is given. The intimate appearance of these nuclei is very different from that of the other cell groups. The cells stain poorly, are mostly smaller, and polygonal in form, though some of the cells in the periphery may be larger. The cells have a vesicular nucleus and contain a yellowish lipoid pigment, shown by Gagel (1928) to stain with fat stains. The ground substance of the nuclear groups is paler than the surrounding substance and "foamy" in character. The whole area is relatively avascular, there being usually a single vessel in the middle of each group with scattered capillaries.

The nucleus mamillo-infundibularis of Greving, or tuberomamillaris of Gagel, consists of fairly large cells, scattered somewhat widely in the region between the tuberal nuclei and the mamillary bodies. The cells are multipolar, and stain well. They have a large nucleus and Nissl granules which are large and tend to protrude round the periphery of the cell, giving it a spiky appearance (Nicolesco, 1929). In old people a dark pigment, possibly melanin, may be found in them. Some of the cells have vacuoles.

The rest of the hypothalamic region is made up of the central grey matter of Greving and others. This consists of a mass of small undifferentiated cells. Certain condensations of this grey matter are differentiated by some authors, but these are difficult to identify or to correlate. Koikegami (1937-8) in his tables has made this attempt, but it seems to result in a mass of names, which have very little to justify them.

The floor of the third ventricle consists of the infundibular recess and its surrounding structures. Tilney (1936) has discussed this region from an embryological standpoint, and has shown that the part of the structure immediately surrounding the recess is related to the neurohypophysis. The cells are small, lying in a loose matrix, with a close resemblance to the structure of the pituitary stalk. He calls this part the "median eminence." This region is very abruptly marked off from the surrounding hypothalamic area. Behind the recessus infundibularis and between it and the mamillary body is a collection of closely packed small round cells lying in the midline. This Tilney considers to be the homologue of the saccus vasculosus.

Fibre Tracts.-The nerve fibres of this region have been described in detail by Greving (1923-6) and by Roussy and Mosinger (1934a, 1935c). As has been said, nearly all the fibres are unmyelinated, hence their course is difficult to trace with accuracy. It appears, however, that there is a subpendymal group of fibres 
passing both vertically and horizontally forming various connections. A tract called tractus supraopticohypophyseus by Greving (1923) is described as passing from the supraoptic nucleus down to the pituitary stalk. Some fibres from the paraventricular nucleus may also pass in this tract. Fibres are also to be seen curving between the supraoptic and paraventricular nuclei, thereby linking these groups of cells. Roussy and Mosinger (1934b) believe that some fibres from the supraoptic nucleus pass into the optic tract and serve as "vegetative connections" for the eye.

Commisural fibres between the main nuclear groups of each side are described with a degree of constancy. The tuberal nuclei lie in a network of fibres; some of these fibres pass down towards the midbrain. Longitudinal fibres may be seen passing into the midbrain from the various nuclei and are connected with the dorsal longitudinal bundle.

It is difficult to determine the direction of the fibres. Laruelle (1934) considers that the shape of the nuclear groups gives an indication of the direction of flow, but taking into consideration the polymorphism of the nuclei a certain amount of caution is required in accepting such a statement. Roussy and Mosinger (1934-5) describe fibre connections with all parts of the brain ; again such statements should be accepted with some reserve.

The presence of fibres in the pituitary stalk has been described by Croll (1928), Pines (1925), Greving (1926b), and many others. Recently Balado (1938) has cast doubts on the presence of these, for he believes that many are neuroglial fibres; he considers that definite evidence of fibres reaching the posterior lobe of the pituitary is still wanting, but accepts the view that some fibres may end in the gland-like follicles situated in the pituitary stalk.

The hypothalamic region has been studied in detail by many authors in a variety of animals-monkeys of various types, dogs, cats, guineapigs, rats, mice, etc. All these studies have been undertaken from the viewpoint of cellular topography. Several variations of the cell groups differing from those found in man have been described. The cell types, however, are relatively the same.

In the preoptic area, occupying the anterior end of the wall of the third ventricle, above the chiasma, some differences are seen. In animals there is a more detailed structure ; there are also lateral and medial cell groups on the wall of the anterior part of the ventricle. These are apparently connected with the median forebrain bundle and the olfactory system. Many consider that the cells in this region do not truly belong to the hypothalamus as it is in fact adjacent to it. Certainly the cell groups are not recognizable in man.

Above the chiasma and on each side of the midline a group of cells called by most writers nucleus suprachiasmaticus, by others (Ranson and Magown (1939) etc.) nucleus ovoideus is to be found. It lies at the level of transition between the preoptic and the hypothalamic regions. This group of cells is especially well marked in carnivora and rabbits, and less marked in the higher mammals. It is not identifiable in man.

The supraoptic and paraventricular nuclei are described as being recognizable in all species, and phylogenetically are the oldest (Hechst (1930) ). Many 
authorities consider that the central grey matter has condensations of the small undifferentiated type of cell. These groups or condensations are given the names of nucleus hypothalamicus ventromedialis, dorsomedialis, ventrolateralis, lateralis, and periventricularis (Fisher, Ingram, and Ranson, 1938). The nucleus mamillo-infundibularis is described by Grünthal $(1930,1935)$ and by Koikegami (1937-8). It is of interest that Roussy and Mosinger (1937) state that in the dog the cells of this nucleus have a melanin pigment as distinct from the yellow pigment described as found in man.

In the lower mammals no structure corresponds exactly with the nucleus tuberis of man, though it is present in the higher apes. The term " nuclei of the tuber" is often used in description of experimental lesions, but it is not clear whether this refers to a specific cell group, or more generally to the central grey matter.

Grünthal (1930), as a result of his comparative anatomical studies, came to the conclusion that in lower animals there was a greater degree of differentiation and that more cell groups were to be distinguished than in the higher animals, and that with evolution there was a progressive simplification of the hypothalamic structure. This view has not met with approval from other writers and recently Koikegami (1937) in a series of comparative studies endeavoured to disprove it. The nomenclature, however, used by Koikegami involves many complicated subdivisions of cell groups, and scarcely seems to clarify the complicated subject.

\section{Vascular Supply}

There is a very rich vascular supply to the hypothalamic region. As has been stated above, the great vascularity of some of the cell groups is indeed remarkable. Le Gros Clark $(1935,1936)$ has described in detail the arterial supply to the hypothalamus in a monkey. He finds that there is a series of direct arterial branches from the circle of Willis, which penetrate the brain to reach the various nuclei. These penetrating vessels are so arranged that each part of the hypothalamus has a supply from the part of the circle of Willis nearest to it. He makes, however, no mention of the venous drainage of this region of the brain.

The relationship of the vascular supply of the pituitary stalk to that of the hypothalamus has given rise to divergent view-points. In 1930, Popa and Fielding gave a description of what they called a hypophyseal-portal venous system. They state that the sinusoids of the anterior lobe of the pituitary unite with the capillaries of the posterior lobe to form large blood vessels which pass up in the anterior wall of the pituitary stalk, where they gain a neuroglial sheath. These vessels are large and tortuous. On reaching the tuber cinereum they break up into a secondary venous network, branches from which penetrate and are distributed to the hypothalamic nuclei, especially the supraoptic, and partly to the paraventricular nucleus. These authors observed balls or droplets of colloid in the lumen of these vessels. They believe that these droplets represent colloid formed in the pituitary and in the process of being 
transported to the hypothalamus. At this level colloid may be seen in contiguity with hypothalamic cells. They hold that as the colloid is formed in the pituitary, the flow in these vessels must be from the pituitary to the hypothalamus.

This view has been confirmed by Basir (1932), who studied injected dog pituitaries. He considered that blood from the anterior pituitary passes partly into the basal circle of veins, but that some passes in the portal veins to the tuber cinereum, where there is an anastomosis of the portal and stalk vessels. He considers that the portal vessels penetrate the tuber, ramify round the chiasma and make capillary plexuses round the cells of the supraoptic nuclei. The paraventricular nucleus is supplied by direct branches from the hypophyseal portal veins, and partly from systemic arteries.

'Espinasse (1933-4) holds that the pituitary artery breaks up into sinusoids in the anterior lobe and that these join up again to form the hypophysealportal vessels which take the blood back to the brain. He considers that these latter vessels are morphologically part of the pituitary artery. He objects to calling these vessels "veins," as the flow in veins should be to the heart and not to the brain. He did not see colloid in the vessels.

Wislocki (1936-8) in a series of papers expresses the view that while the presence of the hypophyseal-portal vessels is confirmed, the direction of flow is not from the pituitary to the hypothalamus, but in the contrary direction. He has injected various animals, and also made embryological studies of human embryos. He states that the pituitary is supplied with blood from the hypophyseal arteries which form a plexus round the pituitary stalk. The interior of the stalk is relatively avascular, though capillary loops may project into it from the plexus. The portal vessels arise from the confluence of small vessels on the surface of the stalk, from plexuses in the pars tuberalis and surface and from the arborizing plexuses of the external surface of the stalk. From these portal venules pass into the anterior lobe. The lateral hypophyseal veins from the sinusoids of the pars distalis drain into the cavernous sinus, as do the veins from the neurohypophysis (pars posterior). He believes that embryonic veins of the pituitary stalk may become obliterated and their place taken by the portal vessels. He found no evidence that there was any connection between the portal vessels and the hypothalamus. At the tuberal end of the stalk the injected vessels end in the median eminence, except for a few capillaries passing into the interior of the infundibulum ; these latter may form connections with the vessels of the hypothalamus. The secondary network of Popa and Fielding (1930) appears to be found in that part of the floor of the third ventricle which comprises the median eminence of the neurohypophyseal structure. Wislocki (1937c) states that by gentle traction of the stalk the whole median eminence separates from the brain, and this part contains the vascular plexuses. Injection of vital dyes shows that the dye is taken up strongly by the neurohypophysis and the median eminence, and that there is a clear line of demarcation ; the hypothalamic nuclei remain unstained. As another argument against the direction of flow postulated by Popa, Wislocki points out that the size of the brain capillaries is so much less than that of the portal vessels that such a flow is mechanically improbable. Popa (1938) makes a rejoinder to Wislocki's 
work. He considers that Wislocki's view is galenical as against a modern view. He describes experiments to support his own view. If the stalk is occluded in a rabbit, blood accumulates in the infundibular end, above the pressure. After section of the stalk, the pituitary end is engorged, while the hypothalamic end is empty. He also asserts that blood from the portal veins reaches the ependyma at the tip of the recesses infundibuli. Balado (1938) has made detailed studies of the structure of the pituitary stalk. He describes the vessels of the stalk as very large and winding, with many branches. Unlike the brain vessels they have no perivascular spaces. He considers that venous blood leaves the stalk by large veins, contrary to the views of Popa and of Wislocki. The question is a complicated one and is yet to be completely answered. This problem is of importance especially from the aspect of the hypophyseo-hypothalamic mechanisms, including that of movements of colloid.

It is of interest that the columnar ependyma of the third ventricle, as pointed out by Basir and since by others, tends to have invaginations, making glandlike clefts. These clefts are commonly situated in the part of the ventricular wall near but rather below the paraventricular nucleus. Some authors have thought these clefts to have some function in connection with the passage of colloid into the cerebrospinal fluid. Towards the tip of the infundibular recess the type of ependyma changes, and becomes more cuboid. Also as has been pointed out by Cushing $(1932,1933)$, it becomes discontinuous. This may readily be interpreted as tears caused by technical errors, but the appearance is too frequent for this explanation to be adequate. F. G. Popa (1934) has made a study of this question and considers that the ependymal floor is missing in some areas, and that a neuroglial floor is present at the tip of the recess. $\mathrm{He}$ thinks the tip is prolonged by digitations which penetrate into the solid core of the pituitary stalk. In man the conelike tip of the recess is short and the pituitary stalk is a solid core of neuroglial and connective tissue fibres. On the anterior surface, but separated by a glial network, are found the glandular elements of the pars tuberalis. This extends varying distances up the stalk from the pituitary, but not over the brain substance beyond the part distinguished as the large vessels which form plexiform follicles penetrating into the external surfaces of the stalk. These follicles are described in detail by Balado.

In various animals the relationship of the third ventricle to the stalk differs. In monkeys the appearance is much as in man. In cats (Tilney (1936), Wislocki, and King (1936)) the infundibular recess is prolongated down the length of the stalk. In dogs (Mahoney and Sheehan (1936), Collin (1934)) the ventricle reaches well down into the short stalk. In rats the stalk is short. These variations of structure assume importance in experimental work. If the stalk is cut or clipped the vascular supply and its connection with the third ventricle varies in detail in the different species.

Colloid.-Two problems which have interested several workers are : first, the distribution of pituitary colloid, and second, the nature and origin of the colloid seen in the cells of the hypothalamic nuclei.

Cushing (1933), Collin (1924-8), and others described the presence of droplets of " hyaline substance of colloid " in the pituitary stalk. These colloid particles 
were seen at first in the interspaces of the neuroglia of the stalk, and consequently investigators considered that the colloid was formed in the anterior lobe of the pituitary and was then transported to the infundibulum and hypothalamus. Cushing (1933) suggested that the colloid forced its way through the ependyma of the infundibular recess and reached the cerebrospinal fluid. It is also possible that other droplets pass up in the tissue spaces to reach the neighbourhood of the hypothalamic nuclei, and further at the level of the paraventricular nuclei penetrate the ependyma to reach the cerebrospinal fluid. Cushing considered that the sponginess of some of the ground substance in the region of the hypothalamic nuclei, might result from fixation methods removing the colloid and leaving empty spaces. Collin (1924-33) in a series of papers has described the methods by which he believes the pituitary colloid to be distributed. Thus colloid may pass direct into the blood stream and the general circulation. This he terms “hæmocrinie." It may pass into the cerebrospinal fluid at the infundibular recess, having travelled in the interstitial tissues. This he designates "hydrencephalocrinie." It may pass into the tuber cinereum by direct transit through tissue spaces, or along perivascular spaces. This he terms " neurocrinie." Again it may pass into hypothalamic nuclei by functional capillaries, through the portal system of Popa and Fielding -so he calls this " hæmoneurocrinie." Collin suggests that colloid reaching the cerebrospinal fluid is quickly dissipated.

Celestino de Costa (1925) thinks that the colloid passes through the perivascular spaces into the vessels and is carried in the vessels.

Roussy and Mosinger (1933-7) in their series of papers have developed Collin's theories of the passage of pituitary colloid. They hold that the pituitary colloid may be carried in the vessels and describe some vessels of the stalk as " colmaté " filled with colloid. This has a similar appearance to that of a thyroid vesicle. In 1934 they described in greater detail the pseudo-degenerative appearance of the cells of some of the hypothalamic nuclei, and the appearance of "droplets " filling up vacuoles in the cells. In some cases the vacuoles were empty of colloid. They considered that the neurones themselves possessed a secretory power apart from the influence of pituitary secretion. They bring forward the hypothesis (1937) that the colloid in nerve cells may be explained by its production within the neurone, or by the resorption by the neurone of pituitary colloid brought by " neurocrinie." The colloid, according to the above authors, may diffuse into the cytoplasm of the cells-a true assimilationand offer the evidence of the paleness of the colloid staining in some vacuoles as evidence to further this hypothesis.

Scharrer (1933) described the apparent pathological changes to be found in the supraoptic and paraventricular nuclei. He found that these appearances were constant in all animals. In snakes large vacuolizations were found with drops of some colloid-like substance lying therein. This also occurred in toads and fish. Scharrer interpreted these findings as indicating some secretory function. Later with Gaupp (1937), he made further studies in human and animal material. These two authors found vacuoles constantly, and also described multinucleated cells in the paraventricular and supraoptic nuclei. 
Colloid was found in many cases, in the early stages, as fuchsinophil granules in van Gieson stained sections. This coalescence of such granules formed the colloid droplets seen in the neurones. Drops were also seen loose near the vessels or in the subependymal layers. An attempt was then made to correlate the appearance of the colloid with the time of year. In some species colloid was found in summer, not in winter, in others the opposite occurred. In reptiles, fish, and invertebrates, similar secretory cells have been found. Hanström (1931), in crustacea, described Organ X, a group of secretory cells attached to the brain, which he considers to be a "brain gland." Weyer (1935) has described, in the honey bee, a gland-like cell complex of several secreting nerve cells, and some non-secreting cells. Newly hatched and old worker bees seem to have no "colloid." Young sexually active bees showed the drops best. Worker bees had a well-marked "gland," queen bees less well-marked and drones no gland. He considered the gland to be a homologue of Organ $\mathrm{X}$ and truly neurosecretory.

Gaupp (1936) and Peters (1936) have studied the presence of colloid in various normal and pathological states. Vacuoles are constant, but colloid is variable. The colloid is insoluble in fat solvents, and gives no reaction with fat stains, nor does it give a glycogen reaction. Gaupp and Peters do not find in the pituitary stalk or its vessels colloid like that seen in the cells, though extracellular droplets may be seen. . Gaupp (1938) has described similar colloid droplets in the cells of the sympathetic ganglia. According to Peters, in a personal communication, no correlation has yet been found between the amount of colloid and any pathological condition, though colloid is less likely to be found in childhood.

The question of the origin of the colloid droplets described is debatable. It is obvious that if colloid is present in sympathetic ganglion cells, it has not been conveyed by the pituitary stalk to those cells. Popa and Fielding used as an argument in favour of the flow of blood in their portal vessels the fact that the vessels contained drops of colloid which must have come from the pituitary. But others have asserted the secretory power of the cells of the pars tuberalis covering the pituitary stalk, and that colloid may be formed there and pass into the portal vessels. The finding of colloid drops and flakes in the interspaces of the stalk and under the ependyma of the recessus infundibuli is confirmed by many, and it may well be that some colloid is excreted by this path. If Wislocki and his followers are right in considering that the vessels of the stalk are more or less self-contained and only serve the secretory activities of the stalk and median eminence, the direct passage of secretion by "hæmocrinie" to the hypothalamic nuclei is made very difficult. Also the nucleus tuberis which is nearest to the infundibulum does not have vacuoles nor colloid in its cells. There are also difficulties in postulating a secretory function of true nerve cells. Yet the appearance of the cells themselves is so unusual ; further their peculiarly close relationship to the capillaries and to the ependymal or pial surfaces, makes it appear possible that these cells may possess some functional capacity of an order uncommon to other nerve cells. The relationship between the hypothalamus and the pituitary body is certainly very close, as evidenced by the 
interaction of blood stream, nerve fibres and the actual presence of colloid. It seems, however, premature to venture any opinion as to the relative importance of these relationships. It is to be hoped that in future experimental work these various problems should be considered together, to permit a more accurate evaluation of the problem as a whole.

\section{REFERENCES}

Abel, J. J. (1924). Bull. Johns Hop. Hosp., 35, 305.

Balado, M. (1938). Zbl. Neurochirurg., 3, 5, 257.

Basir, M. A. (1932). J. Anat., 68, 387.

Clark, W. E. Le G. (1932). Brain, 55, 406.

(1935). Rev. Neurol., 64, 555.

(1936). J. ment. Sci., 82, 99.

Clark, W. E. Le G., Beattie, J., Riddoch, G., and Dott, N. M. (1938). “ The Hypothalamus.” Oliver \& Boyd, London.

(1924a). C. R. Soc. Biol., 91, 1,334.

(1924b). Rev. Franç. Endocrin., 2, 2.

(1924c). Ibid., 2, 381.

(1925a). Ibid., 3, 16.

(1925b). Ibid., 3, 213, 277.

(1926a). C. R. Soc. Biol., 95, 107.

(1926b). Ibid., 95, 686.

(1927). Ibid., 97, 381.

(1928). Arch. gén. exp., 28, 102.

Collin, R. (1933). Ann. Méd., 33, 239.

Celestino da Costa, A. (1925). C. R. Soc. Biol., 92, 1246.

Croll, M. M. (1928). J. Physiol., 66, 316.

Cushing, H. (1932). " Pituitary Body and Hypothalamus." London.

- (1933). Amer. J. Pathol., 9, 539.

'Espinasse, P. G. (1933-4). J. Anat., 68, 11.

Fisher, C., Ingram, W. R., and Ranson, S. W. (1938). “Diabetes Insipidus.” Edwards, London.

Gagel, O. (1928). Z. ges. Anat., 87, 558.

Gagel, O., and Mahoney, W. (1933). Z. ges. Neurol. Psychiat., 148, 272.

Gaupp, R. (1936a). Z. ges. Neurol. Psychiat., 154, 314.

- (1936b). Ibid., 154, 673.

Gaupp, R., and Scharrer, E. (1935). Ibid., 153, 327.

(1937). Ibid., 160, 357.

Gigon, A. (1929). Schweiz. Arch. Neurol. Psychiat., 24, 53.

Greving, R. (1923). Ergbn. Anat. Entw. Gesch., 24, 348.

- (1925a). Z. Anat. Entw., 75, 597.

- (1925b). Ibid., 77, 249.

(1925c). Z. ges. Neurol. Psychiat., 99, 231.

—_ (1925d). Graefe's Arch., 115, 523.

- (1926a). Z. ges. Neurol. Psychiat., 104, 466.

(1926b). Disch. Z. Nervenheilk., 89, 179.

Grünthal, E. (1930). Arch. Psychiat. Nervenkr., 90, 217. (1935). J. nerv. ment. Dis., 81, 1.

Hanström, B. (1931). Z. Morph. Ökol. Tiere., 23, 80.

Hechst, B. (1930). Arch. Psychiat. Nervenkr., 91, 319.

Kappers, A. (1935). Rev. Neurol., 64, 554.

Koikegami, H. (1937-8). Arch. Psychiat. Nervenkr., 107, 742.

Laruelle, L. (1934). Rev. Neurol. 1, 809. (1935). Ibid., 64, 562 .

Leschke, E. (1933). Ann. Méd. 33, 261.

Mahoney, W., and Sheehan, D. (1936). Brain, 59, 61.

Nicolesco, I., and Nicolesco, M. (1929). Rev. Neurol., 36, 289.

Peters, G. (1936). Z. ges. Neurol. Psychiat., 154, 331.

Pines, I. L. (1925). Ż. ges. Neurol. Psychiat., 100, 123.

Popa, F. G. (1934). Vol. Jubilaire C. I. Parhon, Jassy., p. 450.

Popa, G. T. (1934). Vol. Jubilaire C. I. Parhon, Jassy., p. 459.

-G. T. (1938). Pr. Méd., 46, 663. G. T., and Fielding, U. (1930). Lancet, 2, 238. (1930-31). J. Anat., 65, 88.

- (1932-3). Ibid., 67, 227. 
Poppi, U. (1930). Riv. Patol. nerv. ment., 36, 397.

Ranson, S.W., and Magown, H. W. (1939). Ergbn. Physiol. Biol. Chem. exp. Pharmacol., 41, 56.

Recordon, E., and Griffiths, G. M. (1938). Brit. J. Ophthalmol., 22, 353.

Rioch, D. McK. (1929-30). J. comp. Neurol., 49, 1.

Roofe, P. G. (1938). Ibid., 69, 249.

Roussy, G., and Mosinger, M. (1933a). Ann. Méd., 33, 193. $(1933 b) . \quad C$. R. Soc. Biol., 112, 557, 775, 1,048, 1,203, 1,317.

Roussy, G., and Mosinger, M. (1934a). Rev. Neurol. 1, 848. (1934b). Rev. Neurol., 2, 655.

- $(1934 c)$. C. R. Soc. Biol., 115, 1,143.

(1934d). Ibid., 116, 858.

(1934e). Ibid., 117, 1,054 .

(1935a). Ibid., 119, 795, 797, 929, 1,068.

(1935b). Ibid., 118, 414, 324, 736.

(1935c). Rev. Neurol., 63, 1.

(1935d). Ibid., 64, 163.

(1936a). J. Physiol. Pathol. gén., 34, 486

$(1936 b)$. C. R. Soc. Biol., 122, 643, 719, 1,290.

(1937a). Ibid., 126, 1,064.

(1937b). Pr. méd., 54, 433.

Scharrer, E. (1928). Z. vergl. Physiol., 7, 1.

(1933). Z. ges. Neurol. Psychiat., 145, 462.

- (1937). Ibid., 158, 93.

Scharrer, E., and Gaupp, R. (1933). Ibid., 148, 766.

Spiegel, E. A. and Zweig, H. (1919). Arbeit aus Neurol. Inst. Wien., 22, 278.

Tilney, F. (1936). Bull. neurol. Inst. N. Y., 5, 387.

Weyer, F. (1935). Zool. Anz., 112, 137.

Wislocki, G. B. (1937a). Anat. Rec., 67, 273. (1937b). Amer. J. Anat., 61, 95.

- (1937c). Anat. Rec., 69,361.

(1938). “The Pituitary Gland.” Proc. Assoc. Res. nerv. ment. Dis., 17, p. 48. (1938). Anat. Rec., 72, 137.

Wislocki, G. B., and King, L. S. (1936). Amer. J. Anat., 58, 421. 